Reeh, N., Thomsen, H. H. \& Clausen, H. B. in press: The Greenland ice-sheet margin - a mine of ice for palaeo-environmental studies. Palaeogeogr., Palaeoclim., Palaeoecol.

N. R.,

Polar Continental Shelf Project, Energy, Mines and Resources Canada,

Ottawa, Ontario

Canada, K1A OE4.

\title{
Continued glaciological work north-east of Jakobshavn, West Greenland
}

\author{
Henrik Højmark Thomsen
}

Glaciological investigations were carried out on the Inland Ice north-east of Jakobshavn. The work is part of the hydropower investigations at Pâkitsoq on a drainage basin proposed for a local hydropower project. The work was started in 1982, when stakes for measuring mass balance were drilled into the ice. So far the investigations have included mass balance measurements, photogrammetric and satellite mapping, ice-thickness mapping, stable isotope studies, simulation of runoff and ice dynamics (Reeh, 1983; Thomsen, 1983, 1984, 1985; Braithwaite \& Thomsen, 1984; Thomsen \& Braithwaite, 1985; Thomsen \& Reeh, 1986; Reeh \& Thomsen, 1986a; Thorning et al., 1986).

\section{Fieldwork 1986}

Mass balance measurements 1985/1986. The stakes were visited by helicopter on 13 May, 31 July and 25 August (fig. 1). Six new stakes (stakes 2, 21, 22, 23, 24, 25) were established in May. The six new stakes are all located near the ice margin ending in lake 187, and are represented by stake 2 in fig. 1 .

The winter snow cover on the ice was very patchy and confined mainly to drifts in gullies and crevasses up to an elevation about $600 \mathrm{~m}$ a.s.l., whereas it was continuous at higher elevations. The transient balance for the winter period was measured in snow pits, and by depth soundings at the stakes. As there were no signs of heavy melting during the winter, the observed distribution of snow cover is probably due to wind drifting. This year's measurements show a higher snow accumulation in the area compared to the previous two years. The transient annual balances are shown in fig. 2. The 1986 summer ablation is small compared to earlier years. This is mainly due to very limited ablation from May to August. From fig. 2, it can be seen that the annual equilibrium line was between 1000 and $1100 \mathrm{~m}$ a.s.l.

Drainage conditions on the Inland Ice. Surface-drainage conditions were studied by reconnaissance on foot and by helicopter. The reconnaissance was confined to areas where large moulins could be seen on recent aerial photographs. 


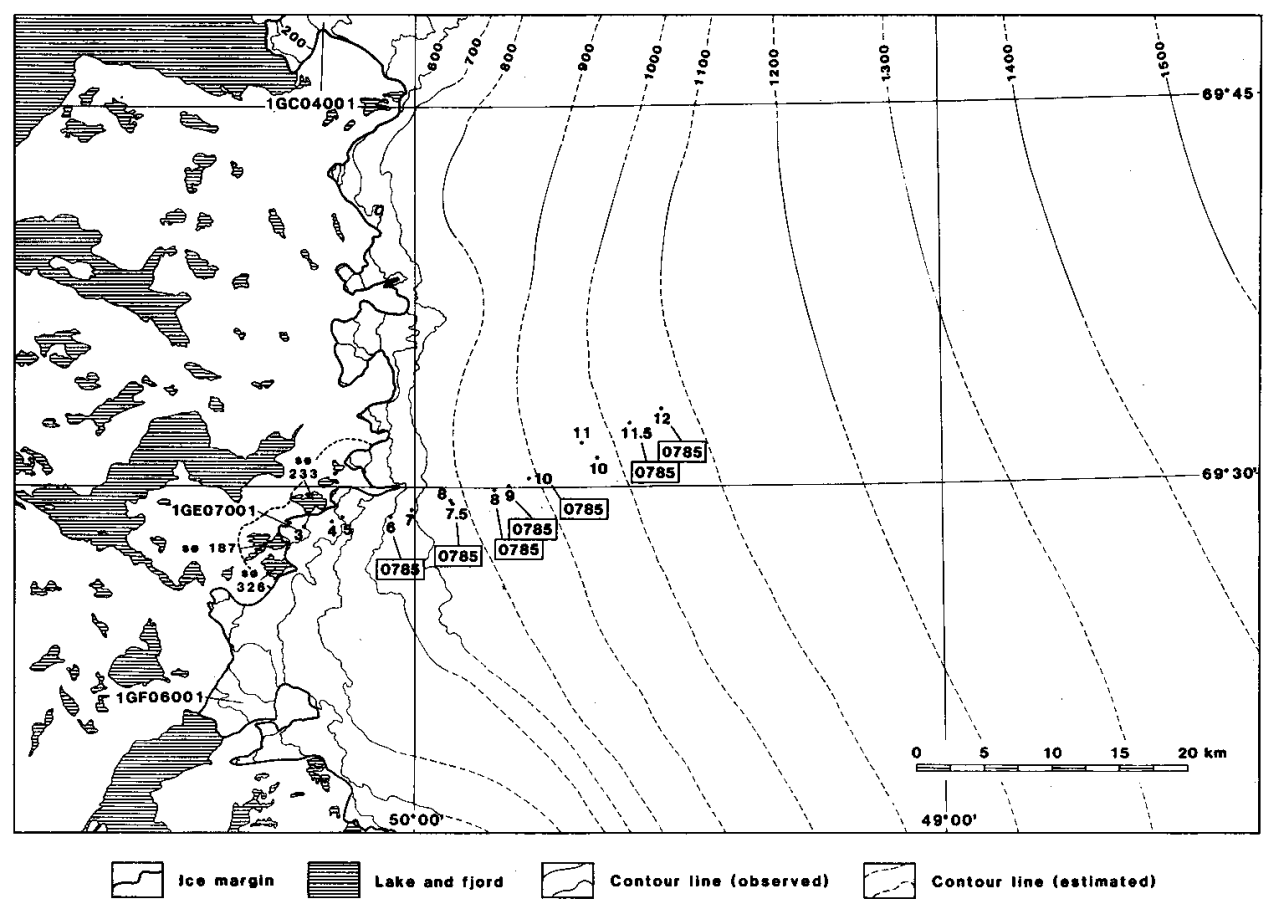

Fig. 1. Drainage basin at Pâkitsoq. Stakes drilled into the ice are shown. Contours in metres. Position of stake 10 is estimated as no survey has been carried out.

At many locations, surface-water drains down into recently opened crevasses starting the formation of new moulins. Downstream from these can be seen dried out river-beds often connecting series of old moulins.

However, this change in surface drainage seems to be of local origin, only taking place within certain limited areas of the ice sheet. Comparison of aerial photographs back to 1948 shows the overall surface-drainage pattern to be rather stable, with large moulin systems lying at approximately the same positions.

Collection of ice and water samples. Simulations of the variation in the oxygen isotope ratio in the meltwater discharge from the marginal zone of the Inland Ice at Pâkitsoq have been carried out (Reeh \& Thomsen, 1986b). The results of the simulation indicate that isotope studies can contribute useful information about elevation distribution in the area and the development of the ablation area through the melt season. To improve the quality of the simulation and thereby provide a background for safer conclusions about the delineation of the hydrological drainage basins on the Inland Ice, ice and water samples were collected in the area.

Water samples were collected from the outlet of the five lakes in the basin: lakes 326,187 , 233, and two smaller lakes north of lake 233 (fig. 1). The sampling was repeated several times during the period from 31 July to 25 August. Surface ice samples were collected along a profile transverse to the ice margin, at the glacier lobe just north of lake 233 . The profile 


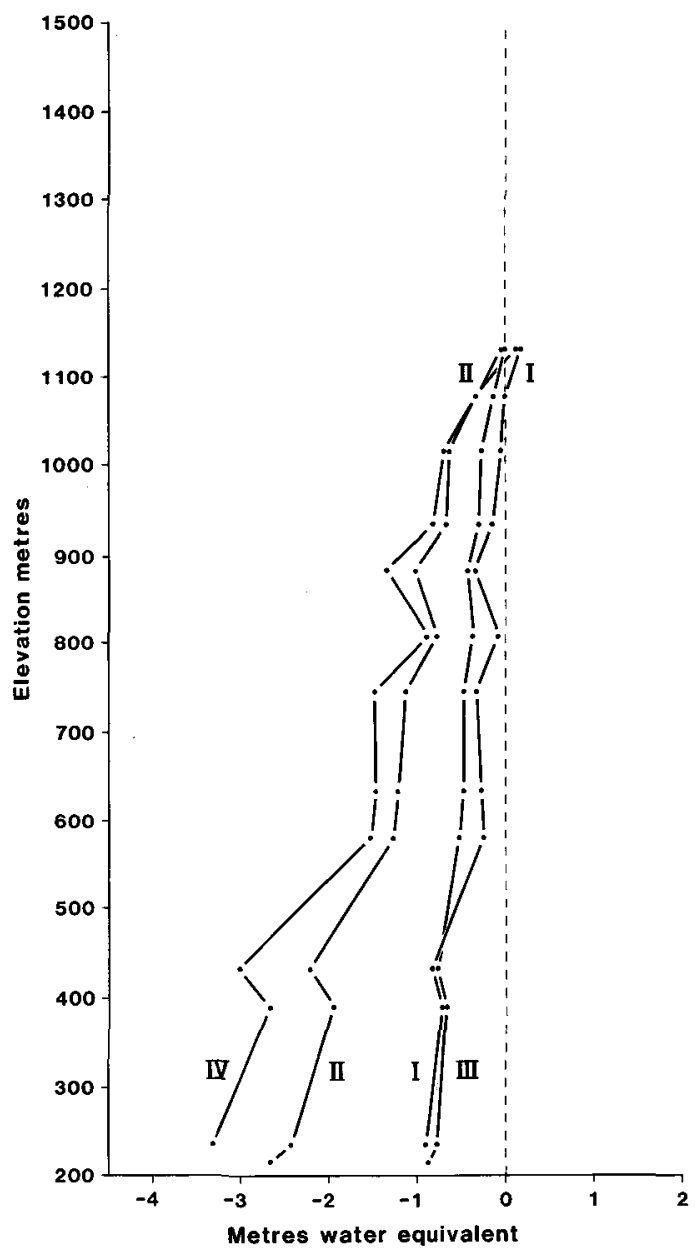

Fig. 2. Mass balance in relation to elevation on the Inland Ice at Pâkitsoq. (I) Transient balance: 7 August $1985-13$ May 1986. (II) Transient balance: 13 May 1986 - 25 August 1986. (III) Transient balance: 31 July $1986-25$ August 1986. (IV) Annual balance: 7 August 1985 - 25 August 1986.

extends from the ice edge and $1850 \mathrm{~m}$ up-glacier from this. Additional ice and water samples were collected from the surface of the ablation zone at different elevations, covering the drainage basins to the individual lakes. The samples collected should give a more detailed description of the isotope distribution within the drainage basin at Pâkitsoq.

The samples collected will be analysed for $\delta^{18} \mathrm{O}$ at the Geophysical Institute, University of Copénhagen during the winter of 1986-1987, and will form the basis for new simulations of the variation in oxygen isotope ratio in the meltwater discharge.

\section{Drainage basin delineation on the Inland Ice}

Work is being carried out on the delineation of drainage basins on the Inland Ice. An icethickness map of the area based on EMR measurements has been produced (Thorning et al., 1986). The map covers the marginal part of the Inland Ice from the ice edge and up-glacier to 
an elevation of about $1200 \mathrm{~m}$. On the basis of the ice-thickness map and existing surface topographical information, subglacial water potentials have been calculated by the method described by Björnsson (1982). The results are being analysed. A new surface topographical map based on aerial photographs from 1985 is under preparation to analyse the changes with time of the surface features.

\title{
References
}

Björnsson, H. 1982: Drainage basins on the Vatnajökull mapped by radio echo sounding. Nordic $\mathrm{Hy}$ drol. 13, 213-232.

Braithwaite, R. J. \& Thomsen, H. H. 1984: Runoff conditions at Paakitsup akuliarusersua, Jakobshavn estimated by modelling. Grønlands geol. Unders., Gletscher-hydrol. Meddr 84/3, 22 pp.

Reeh, N. 1983: Ikke-stationær beregningsmodel for Indlandsisens randzone. Grønlands geol. Unders., Gletscher-hydrol. Meddr 83/7, $81 \mathrm{pp}$.

Reeh, N. \& Thomsen, H. H. 1986a: Stable isotope studies on the Greenland ice-sheet margin. Rapp. Grønlands geol. Unders. 130, 108-114.

Reeh, N. \& Thomsen, H. H. 1986b: Model for simulering af ilt-isotop variationen i smeltevandsafstrømningen fra Indlandsisens rand ved Pâkitsup akuliarusersua, Jakobshavn. Grønlands geol. Unders., Gletscher-hydrol. Meddr 86/1, 34 pp.

Thomsen, H. H. 1983: A glaciological field and mapping programme in connection with hydropower, West Greenland. Rapp. Grønlands geol. Unders. 115, 102-107.

Thomsen, H. H. 1984: Glaciological reconnaissance, mass balance measurements and mapping programmes in connection with Greenland hydropower. Rapp. Grønlands geol. Unders. 120, 95-99.

Thomsen, H. H. 1985: Glaciological field work and remote sensing in connection with hydropower investigations, West Greenland. Rapp. Grønlands geol. Unders. 125, 95-99.

Thomsen, H. H. \& Braithwaite, R. J. 1985: Estimation of runoff for proposed hydropower stations near Jakobshavn and Christianshåb, West Greenland. Rapp. Grønlands geol. Unders. 125, 100-103.

Thomsen, H. H. \& Reeh, N. 1986: Glaciological investigations at the margin of the Inland Ice northeast of Jakobshavn, West Greenland. Rapp. Grønlands geol. Unders. 130, 102-108.

Thorning, L., Thomsen, H. H. \& Hansen, E. 1986: Geophysical investigations at the Inland Ice margin of the Pâkitsoq basin, central West Greenland. Rapp. Grønlands geol. Unders. 130, 114-121.

\section{Electromagnetic reflection survey 1986 at the Inland Ice margin of the Pâkitsoq basin, central West Greenland}

\author{
Leif Thorning and Egon Hansen
}

The first successful application of electromagnetic reflection (EMR) techniques for determination of ice thickness in the outermost margin of the Inland Ice adjacent to the Pâkitsoq basin took place in July 1985 (Thorning et al., 1986). Although the survey was planned as a series of experiments to examine why previous attempts had not worked, the EMR data acquired were of very good quality and could be compiled into a preliminary map of ice thickness and a map of the subglacial topography over part of the region. Thus, by early 1986 it 